\title{
A Study of Moral Education and its Relationship with Character Education
}

\author{
Dr. Nur Silay \\ Koç University \\ E-mail: nsilay@ku.edu.tr
}

\section{Doi:10.5901/mjss.2014.v5n2p353}

\begin{abstract}
The purpose of this paper is to look at thoughts on moral education in detail by educational scientists, the reason why universities need to take care of their students' moral development, and how much related moral education is to character education. It is a try to collect information from findings of various researches. Previous studies show that there are clear links between morals and good character. Sometimes, one refers to the other as they have a lot of qualities in common. In addition, the role of teachers and academics as professionals that are willing to guide their students in their quest for moral identities is highlighted by many researchers. Research results reveal that moral development of students continues during their early years at university. This is why moral education should be an important aspect of university life. It would be right to state that educating the character of students is necessary as well as teaching and researching.
\end{abstract}

Keywords: Moral education, character education

\section{Introduction}

Moral education is a term used by academics in educational sciences extensively. It is relative to character education, which is a widely known movement in the field. This paper aims to briefly review research findings on both moral education and character education so as to compare them by examining the similarities. It also intends to remind academics and administrators in higher education that students' moral development does continue throughout tertiary education years. Hence, moral values of students still can be fostered. Robson defines research review as "having a synoptic aim of putting together and evaluating different kinds of findings in a particular field of interest" (Robson 2000). Since this paper will briefly cover the points of views by different academics on moral education and also highlight the connection between moral education and character education, it should be regarded as a research review.

\section{Morality and Moral Development during University}

According to Candee and Kohlberg, morality could be regarded as having interpersonal behavior which includes the rights, duties, or welfare of either party (Candee \& Kohlberg 1987). In their opinion, an action could be considered moral "if it is consistent with what an actor independently judges to be morally right". Kohlberg argues that choices that are moral duties are choices both for ourselves and all people (Kohlberg 1977). He thinks that moral values are different from other kinds of values in terms of "defining duties and duties as universalizeable". In his view, duties do "imply rights and if moral duties rest on rights, moral values rest on justice."

When the information above is considered, it is understood that for Candee and Kohlberg, morality exists between two individuals and it involves the rights, responsibilities, and well-being of each. The condition for an action to be moral is, its consistency with what an individual freely judges to be morally correct. The key words in the aforementioned quotation are "consistent" and "independently" because they increase the meaningfulness of the definition of a "moral action". Likewise, in an earlier study, Kohlberg emphasizes the fact that moral duties include two parties. In other words, he reminds his audience that morality does not concern only one person, and in fact it is a matter for everybody. Moreover, he regards moral duties as universal and not peculiar to one culture or society only. He clearly makes the connection between moral duties and moral values by highlighting the close link between rights and justice.

In Turiel's opinion, moral development is a process through which children have to go through such as sociological and psychological development; it is a talent to differentiate between right and wrong while evaluating one's own and others' behaviour (Turiel 1998 quoted in Kızltepe 2004). This development starts at very early ages and it continues during lifetime. Students continuosly face moral dilemmas. For instance, should they cheat? Or should they cut their 
classes when the weather is nice? Or should they inform against their close friend who has broken the school regulations and told them about it wishing it to remain as a secret? To find answers to all of these questions, psychologists and researchers have offered some theories and tried to find solutions. There are three moral stages that Kohlberg proposed: pre-tradition, traditional, and post tradition (Kohlberg 1963, 1983, 1984 quoted in Kızltepe 2004). In order to detect which moral stage children are going through, Kohlberg presented certain situation-stories which he called moral dilemmas. The point he was interested in was not what decision children made as a reply to the questions at the end of stories; he was interested in why they made those decisions. In other words, what logical series they had so as to reach their decisions. The decisions are extremely important as it is believed that those decisions reflect children's system of thoughts on moral issues. The last stage is reached after the age of 16 and at this level, the individual has based his moral ideas on some inherent moral absolutes. Those absolutes that she or he has founded may not conform to those of others or the society. This stage has two phases: 1. Social accordance and utility 2. Individual rights and universal rights. During the first phase, the individual gives significance to both social agreements and human rights while trying to balance them. During the second phase, even if the principles of the society she or he lives in are not in accordance, the individual is headed towards principles of universal justice.

In the light of the information above, it could be interpreted that Turiel agrees with Kohlberg on the subject of moral development in the sense that it involves both an individual and other people. Another significant point is that Kohlberg was able to identify three moral stages of children according to why they made different decisions when faced with moral dilemmas. The last stage is especially important as it concerns both high schools and higher education institutions due to the age group of students. Since teenagers reach that stage only after the age of sixteen, it could be deduced that the moral development of young people still continues during the early years of their university life. Therefore, it would not be wrong to suggest that something could be done to help develop the moral values of students while they are at university. Kohlberg's finding is particularly vital for the advocates of moral education in tertiary education.

In Yavuzer's view, adolescence, which is the transition period between childhood and youth, is between the ages of 12 and 21 (Yavuzer 2005). Due to different conditions in societies, acquiring the role of an adult emotionally takes place between the ages of 15 and 24 and this age group is named youth. The term youth is a wide concept that comprises adolescents and early adulthood stage. A research conducted in the capital city of Turkey and another city in southern Turkey found that the adolescence finishes at the age of 21,6 for girls and 23,1 for boys (Çuhadaroğlu et al 2004 quoted in Yavuzer 2005). The last phase of adolescence is known as late adolescence and it includes the period between the ages of 18 and 21. During this phase, identity development is completed and wholeness in identity feeling is reached (Canat 1996 quoted in Yavuzer 2005). Among the factors that have an important role to acquire identity, the following are listed: Choosing a profession, determining a life style, establishing relationships based on love with the opposite gender, developing political, philosophical, religious viewpoints, being in a group and belonging to a group, and forming a values system of one's own.

It seems necessary to point out the fact that Yavuzer means that between the ages of 18 and 21, identity develops. In other words, this process takes three years and the age of 18 is the age when most students in Turkey enroll in higher education institutions. Hence, when their identity begins to develop, they are beginning students at universities. It should be emphasized that this is the time students form their own values system and this is why universities can and ought to play a role in the moral development of their students. The opportunity and duty to assist students throughout their inner journey to themselves should not be overlooked.

\section{Qualities of Moral Education}

In Sandner's opinion, children and young people of today are under the influence of different and intense information and orientation values which may not be comparable to those of the past (Sandner 2001 quoted in Hesapçıoğlu 2004). A consensus of social values does not exist. According to van der Ven, school is not an institution where merely knowledge and skills are offered. It is a full-day pedagogical institution where the roles of parents are taken over to a great extent (van der Ven 2001 quoted in Hesapçığlu 2004). Hesapçıoğlu states that school is becoming a socio-pedagogical institution (Hesapçıoğlu 2004). It is not only a place for learning but it also has a duty that is the part of a private area: giving a life with peers and offering a family-like life. "Just Community School" is a school that tries to apply Lawrence Kohlberg's ideas on moral development and moral education in education and instruction (Hesapçıoğlu 2004). The basic principle of this school is, the building of a school life in terms of a "just community" and taking the responsibility of its consequences. Through this method, it is aimed that the moral norms and rules of living together for students will be mandatory. 
It is clear that Hesapçıoglu does not consider schools merely as institutions of pure instruction. He emphasizes the fact that the role of the school is that of a society which "educates" students. It actually provides students with social circles and takes care of their moral development. The latter function may be regarded as a continuation as moral education starts in the family. By giving information on Just Community School, Hesapçıoğlu explains how justice, morality, and social rules could be taught by focusing on fairness while following Kohlberg's teachings.

Teaching profession has certain established rules, and it is one of the oldest and most respectable professions. Moral principles on which teachers will agree will increase the quality of the service provided and it will also raise professional consciousness (APA 1971 quoted in Kulaksızoğlu 1995). The basic principles that are advised regarding this issue are: 1. Being responsible. 2. Being competent as a professional. 3. Knowing the limits of expertise. 4. Using time effectively. 5. Using appropriate teaching techniques. 6. Being careful towards individual differences. 7. Conveying knowledge. 8. Being objective in measuring and evaluation. 9. Protecting students' interests. 10. Being respectful of students' rights. 11. Obeying rule of confidentiality. 12. Being responsible towards the institution. 13. Respecting the traditions of the society. 14. Being careful while transferring values. 15. Being a role model. A teacher does not only offer knowledge and skills; she or he also leads an individual to have an attitude in certain subjects. The person who helps an individual to interpret knowledge objectively and use it while realizing oneself is also the teacher. The prerequisites of accepting the moral principles above as an individual for a teacher are being able to make original decisions by herself or himself, in harmony with herself or himself, and having a positive professional self (Kulaksızoğlu 1995).

Kulaksızoğlu points out the necessity that a professional in teaching needs to have certain moral principles. A teacher accepts to behave as a leader or guide for his or her students to acquire an attitude, adopt objectivity, and act upon it. To restate, moral principles will both improve the quality of teaching and increase professional understanding. He emphasizes the fact that a teacher should not be considered solely as a knowledge provider.

According to Wardekker, moral education is "concerned with enabling students to critically consider and revise their own commitments in a discursive process, with the help of, among other things, the scientific concepts of ethics, as a part of their reflective construction of their identity narratives" (Wardekker 2004). Therefore, he means that moral education involves discussions among students during which they have to think about their actions analytically and reflect on afterwards. Moreover, he declares that learning moral reasoning (in other words the Kohlberg approach) is beneficial in comprehending intellectually what scientific ideas such as justice mean, and therefore could assist in reflection on the moral quality of actions and decisions by giving intellectual instruments for reflection (Wardekker 2004). Again, he repeats the role of thinking back to one's own actions which leads to self-evaluation and constructive selfcriticism.

Berreth and Berman believe that it is possible to help students to improve their moral values and social skills by way of modeling, instruction, experience and continuous practice (Berreth \& Berman 1997). They list seven principles for a moral school community: " 1 . The school community collaboratively develops, clearly states, and celebrates core moral values. 2. Adults exemplify positive moral values in their work with one another and with students. 3 . The school functions as the hub of the neighborhood community. 4. Students develop skills in goal setting, problem solving, cooperation, conflict resolution, and decision making. 5. Students are involved in decision making within their classroom and school. 6. Educators use a problem-solving approach for discipline. 7. School communities provide opportunities for service - within and outside of the school." (Berreth and Berman 1997). In short, Berreth and Berman give the essential conditions for moral education in a school environment. Similar to previous authors, they echo the role of teachers for the improvement of students' moral values.

\section{Common Aspects of Moral Education and Character Education}

Howard, Berkowitz, and Schaeffer examined the range of character education programs that exist in today's public schools in the United States (Howard et al 2004). Before their examination tough, they prepared a table which presents a taxonomy of programs considered to be and described as character education. In that table, there are ten types of character education. Table 1 below shows four of those types that focus on morals.

Table 1: Partial Taxonomy of Character Education Programs with a Focus on Morals

\begin{tabular}{|l|l|l|}
\hline \multicolumn{1}{|c|}{ Type } & \multicolumn{1}{|c|}{ Major pedagogical approach } & \multicolumn{1}{c|}{ Example } \\
\hline Moral reasoning - & $\begin{array}{l}\text { Discussion of moral dilemmas facilitates } \\
\text { Cognitive } \\
\text { development }\end{array}$ & $\begin{array}{l}\text { Reasoning With Democratic Values: Ethical Problems in } \\
\text { student development of moral reasoning } \\
\text { Cnited States History (Lockwood \& Harris, 1985); Just } \\
\text { Community Approach (Power, Higgins, \& Kohlberg, 1989) }\end{array}$ \\
\hline Moral education - & Academic content (literature, history) used to & The Book of Virtues (Bennett, 1993); Character Counts! \\
\hline
\end{tabular}




\begin{tabular}{|l|l|l|}
\hline Virtue & $\begin{array}{l}\text { teach about moral traditions to facilitate moral } \\
\text { habits and internal moral qualities (virtues) }\end{array}$ & (Josephson Institute, 2001, 2002) \\
\hline $\begin{array}{l}\text { Ethics-Moral } \\
\text { philosophy }\end{array}$ & Ethics of morality explicitly taught & $\begin{array}{l}\text { Moral Questions in the Classroom (Simon, 2001); Philosophy } \\
\text { in the Classroom (e.g., Lipman, 1988); and Socratic } \\
\text { Seminars (e.g., Adler, 1982; Gray, 1989; Strong, 1996) }\end{array}$ \\
\hline $\begin{array}{l}\text { Religious } \\
\text { education }\end{array}$ & $\begin{array}{l}\text { Character education taught in the context of a } \\
\text { faith tradition, justifying morality from a } \\
\text { transcendent source }\end{array}$ & The Virtues Project (Popov, 2000) \\
\hline
\end{tabular}

Howard et al. (2004) Politics of Character Education, pages 197 \& 198

Damon and Gregory state that moral development curricula have entered schools and teacher training programs in Israel, Europe, and North America (Damon \& Gregory 1997). They add that by 1996, there were more than 150 centres for "character education" in the United States. Campbell reports that Sockett offers four elements of a teaching career: Character, commitment, subject knowledge, and pedagogy (Sockett 1993 quoted in Campbell 1996). She also mentions that these elements embody a moral and intellectual dimension in which "the intellectual career involves the growth of wisdom, and the moral career involves development of virtue".

Arthur observes that, "at the outset that in Britain the common language used in educational discourse for the main elements of 'character education' has been 'moral education' and, in more recent times, 'values education' " (Arthur 2005). He explains that the latter two concepts are broader in scope and less specific about the constituents of character education. As a result, he concludes that character education is a specific approach to moral or values education.

One can see that character education and moral education are intertwined concepts when the above mentioned researchers' findings are taken into account. Arthur even reveals the fact that they have used these terms interchangeably along with values education as well. In addition, the classification by Howard et al shows moral education as one kind of character education.

Astin and Antonio conducted a research on the influence of higher education on character development (Astin \& Antonio 2004). They chose dependent variables to complement and extend the literature on the moral and civic development of college students. Three of them were composite measures whose constituent variables were derived through exploratory factor analyses: civic and social values, cultural awareness, and volunteerism. They also anticipated that institutions promoting community service and volunteerism and those valuing diversity would be more likely to contribute to students' character development. Table 2 below shows the composite measures.

Table 2: Composites Developed By Factor Analysis

\begin{tabular}{|l|l|}
\hline Civic and Social Values & $\begin{array}{l}\text { - Participate in community action program } \\
\text { - Help to promote racial understanding } \\
\text { - Influence social values } \\
\text { - Develop a meaningful philosophy of life } \\
\text { - Be involved in environmental cleanup } \\
\text { - Help others who are in difficulty }\end{array}$ \\
\hline Cultural Awareness & $\begin{array}{l}\text { - Acceptance of people of different races and cultures } \\
\text { - Knowledge of people of different races and cultures }\end{array}$ \\
& - Ability to work cooperatively \\
- Understanding of community problems
\end{tabular}




\begin{tabular}{|l|l|}
\hline & $\begin{array}{l}\bullet \text { Hire more women faculty and administrators } \\
\bullet \text { Many courses include feminist perspectives }\end{array}$ \\
\hline
\end{tabular}

Astin, H. S. \& Antonio, A. L. (2004) The Impact of College on Character Development, page 63

Anderson defines character as "moral excellence and firmness" (Anderson 2000). She accepts that "integrity refers to a code of moral values". In her opinion, character and integrity are mutually dependent on each other and this is why they are not separate in effective educational programs. There are four common core character traits as she proposes: hard work, respect, responsibility, and fairness (Anderson 2000).

Glanzer and Milson suggest that two approaches to moral education began to dominate American public schools during the early 20th century: "a) a form of traditional character education that sought to teach traditional virtues, b) progressive approaches to character education that focused on 'the ability to act efficiently and thoughtfully in the cause of social improvement' " (McClellan 1999 quoted in Glanzer \& Milson 2006). They also provide the information that since 1993, 23 states in the United States "have either passed new legislation related to character education or revised existing legislation addressing moral education".

The presence of morals in character education is repeated by Anderson, Glanzer, and Milson. Obviously, moral values are inseparable from good character. Glanzer and Milson consider character education as an approach to moral education. These researchers agree with their colleagues whose names have been mentioned earlier.

Reetz and Jacobs at the University of South Dakota conducted a research by using a survey (Reetz \& Jacobs 1999). The aim of the survey was to determine if and how the School of Education faculty were addressing common issues and themes typically associated with moral and character education. According to the findings, a list of moral and character values was made. The entire list of these values is shown in Table 3 below in descending order of frequency.

Table 3: Moral and Character Education Values Taught by Faculty

\begin{tabular}{|l|c|c|}
\hline \multicolumn{1}{|c|}{ Value } & Taught to Students * & Methods Taught to Students * $^{*}$ \\
\hline Acceptance of Diversity & 97 & 76 \\
\hline Cooperation & 97 & 82 \\
\hline Professional Ethics & 94 & 61 \\
\hline Decision Making & 91 & 70 \\
\hline Commitment & 88 & 58 \\
\hline Effective Use of Resources & 88 & 70 \\
\hline Empathy/Perspective Taking & 88 & 67 \\
\hline Integrity & 85 & 48 \\
\hline Respect for Physical and Mental Health & 82 & 61 \\
\hline Work Ethic & 82 & 55 \\
\hline Dependability / Trustworthiness & 82 & 61 \\
\hline Honesty & 82 & 55 \\
\hline Civility / Courtesy & 79 & 67 \\
\hline Compassion & 79 & 58 \\
\hline Building a Sense of Community in the Work Place & 76 & 64 \\
\hline Self-Esteem & 73 & 67 \\
\hline Conflict Resolution & 73 & 73 \\
\hline Civic Responsibility & 73 & 55 \\
\hline Educating for Diversity & 70 & 61 \\
\hline Perseverance & 70 & 45 \\
\hline Teaching Students to Cope with Adversity & 64 & 52 \\
\hline Self Control & 48 & 58 \\
\hline Respect for the Natural Environment & 36 & 30 \\
\hline Peace / Justice Education & 30 & 30 \\
\hline
\end{tabular}

Additional values listed under "Others": Caring, Life Satisfaction, Love, * Do you teach this value to your college students?,

** Do you instruct your students on how to teach this value to their clients, faculties, or students?

Reetz, L. J. \& Jacobs, G. M. (1999) Faculty Focus on Moral and Character Education, pages 210 \& 211

Kagan expresses that educators are able to address the breakdown of society and morality among students by "making character education a part of the school's core curriculum" (Kagan 2001). He emphasizes that school shootings are one 
symptom of a bigger problem: mutual caring, moral orientation, and breakdown of society. Boyer claimed that "higher education must be a place not only to cultivate the habits of the mind but also to educate for character, transmit values, and provide a forum of preparation for citizenship, leadership, and responsible behavior" (Boyer 1987 quoted in Dalton \& Henck 2004). According to Dalton and Henck, about twenty years later higher education made progress in responding to his call by concentrating on reform of the curriculum and co-curriculum to improve ethical and intellectual advancement (Dalton \& Henck 2004). In their opinion, "achieving a better understanding of the complex interrelationships of intellectual, affective, and behavioral factors that contribute to development of moral character" is a significant challenge for promoting character in higher education.

In summary, moral education and character education share lots of common characteristics. One cannot be thought of without the presence of the other. They are highly interrelated currents that have very similar goals. Higher education institutions are the last step of formal education and as students' moral development still continues during university years, these institutions should do everything in their power to help them grow into responsible and virtuous citizens with positive character traits.

\section{Conclusion}

To conclude, moral education is closely connected to character education and universities should not ignore their students' moral development. The two concepts resemble each other in many ways and sometimes one has replaced the other one in terms of "names" as they seem almost identical. Higher education institutions should assist students during their journey to find their moral selves laden with values. Thus, moral education needs to be considered seriously by universities.

\section{References}

Anderson, D. R. (2000). Character education: Who is responsible? Journal of Instructional Psychology, 27 (3), 139 - 142.

Arthur, J. (2005) The re-emergence of character education in British education policy. British Journal of Educational Studies, 53, (3), 239 $-254$.

Astin, H. S., \& Antonio, A. L. (2004). The impact of college on character development. New Directions for Institutional Research, 122, 55 -64 .

Berreth, D. \& Berman, S. (1997) The moral dimensions of schools. Educational Leadership, 54 (8), 24 - 27.

Campbell, E. (1996) The moral core of professionalism as a teachable ideal and a matter of character. Curriculum Inquiry, 26 (1), 71 80.

Candee, D. \& Kohlberg, L. (1987) Moral judgment and moral action: A reanalysis of Haan, Smith, and Block's (1968) free speech movement data. Journal of Personality and Social Psychology, 52 (3), 554 - 564.

Dalton, J. C., \& Henck, A. F. (2004). Introduction to assessing character outcomes in college. New Directions for Institutional Research, $122,3-6$.

Damon, W. \& Gregory, A. (1997) The youth charter: towards the formation of adolescent moral identity. Journal of Moral Education, 26 (2), $117-130$

Glanzer, P. L., \& Milson, A. J. (2006). Legislating the good - a survey and evaluation of character education laws in the United States. Educational Policy, 20 (3), 525 - 550.

Hesapçıoğlu, M. (2004) Eğitim ve okul alanındaki çağdaş gelişmeler ve bu gelişmelerin eğitim yönetimine yansımaları. Yaşadıkça Eğitim, 82, $7-14$

Howard, Robert W., Berkowitz, Marvin W. \& Schaeffer, Esther, F., (2004), Politics of character education. Educational Policy, 18 (1). [Online] Available: http://dev.csufresno.edu/kremen-dev/bonnercenter/documents/Politics.pdf (October 17, 2013)

Kagan, S. (2001). Teaching for character and community. Educational Leadership, 59 (2), 50 - 55.

Kızıltepe, Z. (2004) Öğretişim - Eğitim Psikolojisine Çağdaş Bir Yaklaşım, İstanbul, Merteks

Kohlberg, L. (1977) The implications of moral stages for adult education. Religious Education, 72 (2), 183 - 201.

Kulaksızoğlu, A. (1995) Öğretmenlik mesleğinin ahlâk ilkeleri konusunda bir deneme. Marmara Üniversitesi Atatürk Egitim Fakültesi Egitim Bilimleri Dergisi, 7, 185 - 188.

Reetz, L. J. \& Jacobs, G. M. (1999) Faculty focus on moral and character education. Education, 120 (2), 208 - 212.

Robson, C. (2000). Real world research - a resource for social scientists and practitioner-researchers. Oxford: Blackwell Publishers Ltd. Wardekker, W. (2004) Moral education and the construction of meaning. Educational Review, 56 (2), 183 - 192.

Yavuzer, H. (2005) Gençleri Anlamak: Ana-Babaların En Çok Sorduğu Sorular ve Cevaplarılla, İstanbul, Remzi Kitabevi 